\title{
Evaluation of the Spermate Quality of Cattle Players Through the use of Conventional Seminal Evaluation Systems and Casa System
}

\author{
Dina Maricela Veloz Veloz ${ }^{* 1,2}$, Nelson Rene Ortiz Naveda ${ }^{\mathbf{1}}$, Manfredy Ismael Chugnay ${ }^{\mathbf{1}}$, \\ Victor Manuel Alvear Velasquez ${ }^{2}$, Carlos Mestanza Ramon ${ }^{1}$ \\ ${ }^{1}$ Escuela Superior Politécnica de Chimborazo, Extensión Norte Amazónica, Sede Orellana, Puerto Francisco de Orellana, \\ Orellana 51002, Ecuador; \\ ${ }^{2}$ Laboratorio de Reproducción Animal - Androgenetic.
}

\begin{abstract}
The objective of this study was to compare the results of some parameters of seminal quality of bulls obtained by the Conventional method and also by the computerized CASA system, other objective was to determinate if there is any difference in seminal quality between Jersey, Holstein and Brown Swiss bulls. Semen samples were collected from 5 bulls and were analyzed by the conventional method which parameters are: Individual motility (\%), Mass motility (1-5), Neubauer chamber concentration $(106 \mathrm{spermatozoa} / \mathrm{ml})$ and individual post-freezing motility $(\%)$. The same samples were analyzed by CASA method, which variables are: Total motility $(\%)$, Progressive motility $(\%)$, concentration (106 spermatozoa/ml) and total post-freezing motility (\%). Results obtained by each breed of bulls in these parameters were compared using a Duncan multiple range test to assess statistical differences. The result was that Jersey bull's semen had the higher counts for most $o$ the variables compared with the other two. The entire population of results by the Conventional method was also compared against the entire population of results by CASA, in those parameters that are equivalent between the two methods: motility (individual vs total), concentration (Neubabuer vs CASA) and post-freezing motility. This comparison was performed with a Student test that proved there were differences between the two methods in all the studied parameters. In the case of motility, the conventional method showed an average $79 \%$ against the $75.56 \%$ of the CASA system. In concentration, the conventional method had a result of $\mathbf{7 6 2 . 8 3}$ million spermatozoa/ml which was inferior that the 819.3 millions spermatozoa/ml of the CASA method. Finally, about the post-freezing motility the conventional method had the highest result with $65.36 \%$ against the $59.64 \%$ of CASA. The conclusion was that the numeric results of spermatic quality are different depending on which method is used.
\end{abstract}

Keywords- Semen, CASA Evaluation, Conventional Evaluation, Motility, ConcentratioN.

\section{INTRODUCTION}

The analysis of seminal quality represents a valuable tool to evaluate the fertilizing potential of males of different species and complements the physical assessment of the animal (Montes, Torres, Rugeles, Almanza, \& Guimarães, 2012). The seminal analysis or spermiogram includes a series of tests that evaluate various factors or functions of the sperm cell. (Quintero, 2003)

According to (Muiño, et al., 2005), among the disadvantages of the classical techniques used to evaluate the seminal quality are the subjectivity of the same, since the results depend in large part on the expertise of the evaluator. When semen is evaluated, seminal quality is studied, which is determined by the comparison of the parameters obtained with the values that are considered normal for an adult reproductive bull. (Vera Muñoz, 2008)

For several decades, many researchers have devoted much work and resources to try to eliminate the subjectivity inherent in the microscopic evaluation of semen quality. Fruit of these investigations was the development of computerized systems for the analysis of sperm motility. (Cuberlo \& Rodríguez, 2013). The development of new technologies for the objective evaluation of sperm, generically called CASA (Computer Assisted Sperm Analysis), has enabled the rapid and reliable assessment of both the kinetic and morphometric variables of the sperm. (Mailbox, 2013)

The analysis of computer-aided semen (CASA) has allowed an objective measurement of many parameters of semen mobility and morphology, offering more reliable, impartial and repeatable measurements with respect to visual examination (Magistrini et al., 1996; Colenbrander et al. 2003, Graham \& Mocé, 2005)

Many researchers, specialists in animal reproduction are trying to design the "ideal seminal analysis", which adequately assess and predict the fertility of a seminal sample in the most accurate way possible. Thus, the analysis of ideal semen would be one that in a simple and effective way would allow to know in a predictive way the fecundating capacity of an ejaculate. (Mellisho, 2010)

In the following work the following objectives are proposed:

1. Compare data on seminal quality values by breed using the conventional evaluation system.

2. Compare data on seminal quality values by race using the Computer Aided Seminal Analysis (CASA) system.

3. Determine if there are differences between the values of the seminal quality determined by means of the conventional method and with the CASA system 


\section{MATERIALS and METHODS}

\section{Materials - Study Area.}

The research was carried out in the National Center of Production and Genetic Improvement "El Rosario", located in Tambillo, canton Mejía, province of Pichincha, belonging to the Ministry of Agriculture, Livestock, Aquaculture and Fisheries. Located at 3000 masl, with a cold temperate climate and an average temperature of $10^{\circ} \mathrm{C}$. Samples will be collected, evaluated and processed in the Genetic Material Processing Laboratory of the aforementioned plant.

We selected 5 breeding bulls housed in the Central, distributed in the following breeds: 2 Holstein Friesian bulls, 1 Jersey bull and 2 Brown Swiss bulls, aged between 18 and 36 months.

For the collection of semen, the method of the artificial vagina was used, from each player 11 different ejaculates will be evaluated, the same ones that will be collected once a week.

Variables analyzed for

- Total motility

- Progressive motility

- Motionless

- Sperm concentration (CASA and Neubauer)

Experimental design and statistical tests

The data obtained were analyzed using the statistical program SPSS 22, according to a Completely Random Design. A Duncan media separation test was performed to determine significant differences in the seminal parameters between the three races included in this study.

Additionally, the measurements obtained through the conventional system and the CASA system of the variables under study were compared using the Student's means comparison test. A total of three comparisons were made: Individual (conventional) Motility vs. Total Motility (CASA), Neubauer (Conventional) vs. Concentration (CASA), and PostFreeze Motility equally between both methods.

\section{RESULTS AND DISCUSSION}

Seed quality values by breed using the conventional evaluation system.

\section{Individual Motility}

When evaluating the individual motility percentage (MI), the Jersey race presented higher MI with an average $86.81 \%$ while for Holstein and Brown Swiss their percentages are lower $80.68 \%$ and $73.41 \%$ respectively; values that are lower than those obtained by (Moncayo, 2016) in which it varies between $85 \%$ and $96 \%$ for the Holstein and Brown Swiss races; in this sense Rubio et al. (2007) independently of the bovine race obtain MI of 62.91\%; however, (Vera Muñoz, 2008) qualifies ejaculates with MI above $80 \%$ as very good corresponding to the values obtained for Holstein and Jersey and a Good rating for ejaculates with MI of $70-80 \%$ corresponding to Brown Swiss. The data obtained are within the minimum requirement for the classification of a bull as potentially satisfactory in the reproductive evaluation proposed by the International Society of Teriogenology, this is mentioned (Paez \& Corredor, 2014)

\section{Concentration - Neubauer}

The sperm concentration obtained by the method of counting with the neubauer chamber presented a higher concentration for the Jersey race with an average of $1036.77 \pm$ $3.22 \times 106 \mathrm{spz} / \mathrm{ml}$, followed by Holstein with an average of $816.20 \pm 3.05 \times 106 \mathrm{spz} / \mathrm{ml}$ and a lower concentration for Brown Swiss with an average of $572.41 \pm 2.35$ x $106 \mathrm{spz} / \mathrm{ml}$, which agrees with the study carried out by (Moncayo, 2016), where it mentions that the Holstein breed showed a higher sperm concentration with an average of 699, 3 x $106 \mathrm{spz} / \mathrm{ml}$ and the Brown Swiss breed showed lower concentration among the breeds under study with an average of 391.7 x $106 \mathrm{spz} / \mathrm{ml}$, this study related it to the results of (Medina, Sanchez, Velasco, \& Cruz, 2007 ), in which they reported an average sperm concentration of $434.5 \pm 41.6 \times 106 \mathrm{spz} / \mathrm{ml}$. On the other hand (Kumar U., et al., 2015) in the evaluation of semen quality in pure bulls and mestizos of jersey race, as a result obtains that, the average concentration of spermatozoa in the pure and crossed Jersey bulls was $1171.01 \pm 56.09$ and $1093.488 \pm 48.25$ million / $\mathrm{ml}$.

According to (Palma, 2009), an ejaculate is considered good if it contains a number greater than $800 \times 106$ sperm per milliliter, on the contrary an ejaculate is bad when the number of sperm per milliliter is below $500 \mathrm{x} 106$. In the same way affirms Porras (2009) mentioning in his manual that, an ejaculate is considered of very good concentration to contain between 750 and $1000 \times 106$ sperm per milliliter and with a regular rating to contain between 250 and $400 \times 106$ sperm per milliliter .

(Palma, 2010), mentions that there is a considerable error in the determination of sperm concentration by means of the Neubauer chamber, since this varies in direct relation to the reduction of the surface considered in the count, when using uncalibrated coverslips, In addition, the error increases with the concentration of the sample (ejaculated 7 to $10 \%$ ). To this they agree (Rodríguez, Franco, \& Jiménez), where they mention that the variability of the results can be from 7.1 to $12 \%$, however, it is a technique that requires experience to perform it properly and takes around 15 minutes per sample. (Palma, 2010), in his study also mentions that the variation could be significantly lower (Coefficient of variation, $\mathrm{CV}=12.3$ ), indicating that the accuracy of the determination varies with laboratories and personnel.

Table 1. Comparison of seminal parameters of the conventional method among three breeder breeds.

\begin{tabular}{|c|c|c|c|}
\hline Raza & $\begin{array}{c}\text { Motilidad } \\
\text { individual } \\
(\%)\end{array}$ & $\begin{array}{l}\text { Neubauer } \\
\left(10^{6} / \mathrm{ml}\right)\end{array}$ & $\begin{array}{c}\text { Motilidad } \\
\text { Postcongelación } \\
(\%)\end{array}$ \\
\hline Jersey & $86.81 \pm 1.81^{\Omega}$ & $\begin{array}{c}1036.77 \pm \\
3.22^{\mathrm{a}}\end{array}$ & $73.18 \pm 2.36^{a}$ \\
\hline Holstein & $80.68 \pm 1.11$ & $\begin{array}{c}816.20 \pm \\
3.05^{b}\end{array}$ & $67.72 \pm 1.53^{a}$ \\
\hline $\begin{array}{l}\text { Brown } \\
\text { Swiss }\end{array}$ & $73.41 \pm 1.06^{c}$ & $\begin{array}{c}572.41 \pm \\
2.35^{c}\end{array}$ & $59.09 \pm 1.82^{b}$ \\
\hline
\end{tabular}




\section{Motility Post freezing}

In the case of Post-Freeze Motility Jersey it obtained the highest results $73.18 \%$, which are statistically equal to those of Holstein 67.72\%, both being better than Brown Swiss 59.09\%.

In a study carried out by (Kumar U., et al., 2015) postfreezing motility is $46.11 \%$, being lower than those obtained in this study, likewise, Cabrera and Pantoja (2012) in their investigation of sperm viability and acrosome integrity in frozen semen from national bulls they show values lower than 63\%; while Madrid-Bury (2005) obtained greater responses to this study $76.7 \%-85.5 \%$. The lost percentage of post-freezing motility is minimal and they are within the parameters established by the Central to qualify as viable a lot.

\section{Masal Motility}

Table 2. Contingency table with the distribution of results of Masal Motility, parameter of the conventional method.

\begin{tabular}{lllll}
\hline \multirow{2}{*}{ Raza } & \multicolumn{4}{c}{ Motilidad masal $(1-5)$} \\
\cline { 2 - 5 } & 2 & 3 & 4 & 5 \\
\hline \multirow{2}{*}{ Brown Swiss } & 0 & 13 & 9 & 0 \\
Holstein & 3 & 4 & 3 & 12 \\
Jersey & 0 & 0 & 6 & 5 \\
\hline
\end{tabular}

The results of the measurements of mass motility are observed, which is measured on a scale of 1 to 5 . None of the observations obtained a result of 1 , and the only three observations that were assigned a value of 2 , belong to Holstein. An exact Fisher test was carried out which resulted in a value of 32.3, which indicates with a degree of significance of $>0.001$ that there was a relationship between the Race variable and the variable Mass motility, in short if there are statistical differences between the races; These resulting values are similar to those revealed by Muiño (2008).

These characteristics are within the parameters established for bulls in reproductive activity according to (Palma, 2011); In this regard Mellisho (2010) mention that for the evaluation of fresh semen the best indicator is the MM.

Seed quality values by breed using the CASA computerized evaluation system

Table 3. Comparison of seminal parameters of the CASA method among three breeder breeds.

\begin{tabular}{|c|c|c|c|c|c|}
\hline Raza & $\begin{array}{l}\text { Concentraci } \\
\text { ón }\left(10^{6} / \mathrm{ml}\right)\end{array}$ & $\begin{array}{c}\text { Motilid } \\
\text { ad } \\
\text { total } \\
(\%)\end{array}$ & $\begin{array}{c}\text { Motilida } \\
\text { d } \\
\text { progresi } \\
\text { va (\%) }\end{array}$ & $\begin{array}{l}\text { Inmóvil } \\
\text { es (\%) }\end{array}$ & $\begin{array}{c}\text { Motilidad } \\
\text { Postcongela } \\
\text { ción (\%) }\end{array}$ \\
\hline $\begin{array}{l}\text { Jerse } \\
y\end{array}$ & $\begin{array}{l}1237.23 \pm 23 \\
04^{\Omega a}\end{array}$ & $\begin{array}{c}77.03 \pm \\
2.2^{\mathrm{a}}\end{array}$ & $\begin{array}{c}70.23 \pm \\
2.66^{a}\end{array}$ & $\begin{array}{c}20.22 \pm \\
0.95^{b}\end{array}$ & $\underset{\mathrm{ab}}{60.43 \pm 2.23}$ \\
\hline $\begin{array}{l}\text { Holste } \\
\text { in }\end{array}$ & $\begin{array}{c}820.67 \pm 13.1 \\
9^{b}\end{array}$ & $\begin{array}{c}79.50 \pm \\
1.99^{a}\end{array}$ & $\begin{array}{c}72.53 \pm \\
1.80^{\mathrm{a}}\end{array}$ & $\begin{array}{c}20.39 \pm \\
0.99 \mathrm{~b}\end{array}$ & $63.24 \pm 1.54 \mathrm{a}$ \\
\hline $\begin{array}{l}\text { Brown } \\
\text { Swiss }\end{array}$ & $\begin{array}{c}608.98 \pm 15.1 \\
2^{c}\end{array}$ & $\begin{array}{c}70.88 \pm \\
1.62^{\mathrm{b}}\end{array}$ & $\begin{array}{c}63.20 \pm \\
1.62^{\mathrm{b}}\end{array}$ & $\begin{array}{c}28.21 \pm \\
1.20^{a}\end{array}$ & $55.65 \pm 1.54^{b}$ \\
\hline
\end{tabular}

When a CASA system is used, it must be taken into account that the results it provides are only applicable and repeatable in another seminal analysis laboratory, as long as the same equipment is used.

There is a comparison between races of the parameters of the CASA method; in this respect for the parameters Concentration, Total Motility, Progressive Motility and Postfreezing Motility the Jersey race was the one that obtained the highest values, in some cases: total motility, progressive motility and post-freezing, there were no differences between Jersey and Holstein.

The only parameter in which Brown Swiss had statistically higher values was in the Immobiles.

Comparison of means between the conventional method and the CASA method.

Table 4. Comparison of means between analogous parameters of the conventional method and the CASA method.

\begin{tabular}{ccc}
\hline Parámetro & Resultado CASA & $\begin{array}{c}\text { Resultado } \\
\text { Convencional }\end{array}$ \\
\hline $\begin{array}{c}\text { Motilidad }(\%) \\
\begin{array}{c}\text { Concentración } \\
\left(10^{6} / \mathrm{ml}\right)\end{array}\end{array}$ & $75.56 \pm 1.25^{\Omega *}$ & $79.00 \pm 0.98$ \\
$\begin{array}{c}\text { Motilidad Post } \\
\text { congelación }(\%)\end{array}$ & $59.64 \pm 1.07^{*}$ & $65.31 \pm 14.06^{*}$ \\
\hline Indicates significant difference, determined by Student's Test \\
$\Omega$ Values correspond to mean \pm Standard error $(\mathrm{n}=22$, for Jersey $\mathrm{n}=11)$
\end{tabular}

In the case of motility, the analogous parameters were compared Individual Motility (Conventional) and Total Motility (CASA); for concentration were compared: Neubauer (conventional) with CASA concentration, and for post-freezing motility the comparison between the two homonymous variables of the two methods was made. The $T$ values obtained in one of these comparisons were: $2.16,2.08$ and 3.42 respectively, all of which exceed the tabular $\mathrm{T}$ value, determining that there were differences in all cases with a significance of $0.033,0.033$ and 0.001 respectively.

Guzmán (2013) in a similar investigation, shows the statistical correlation between both methods, obtaining numerical differences, for the concentration of 0.866 and for the motility of 0.420 , statistically does not obtain significant differences between the seminal characteristics.

(Agüero, 2012), in his study shows that he does not obtain differences between the individual motility measured through routine tests $(57.1+5.6 \%)$ and the individual motility measured through the CASA system $(58.2+7,0 \%)$, obtaining a high correlation between both methods $(\mathrm{r}=0.60, \mathrm{P} \leq 0.008)$, indicating that the latter method is an instrument that can be used in the routine evaluation of fresh semen in the laboratory.

Traditional techniques of evaluation of sperm motility, although they are common, fast and practical, present a subjective character that implies a great variation in laboratories that ranges from 30 to $60 \%$. This may be due to the fact that they are subject to different interpretations that depend to a great extent on the operator's experience, which causes a human 
error, which plays a definitive role in the selection of reproducers Rodríguez and Martínez (2003). The different CASA instruments have demonstrated high levels of accuracy and reliability using different sperm classification methodologies (Verstegen, Iguer-Ouada, \& Onclin, 2002)

Jouannet, P and collaborators (1976), mention that, motility is mainly determined by microscopic observation. Subjectivity, lack of precision and variability of results are important disadvantages. The main problem is related to the standardization and optimization of equipment and procedures.

\section{CONCLUSION}

On the results obtained in this research and when assessing the seminal quality in three races, it is concluded that both the values of the seminal quality evaluated by the conventional and computerized system show differences between breeds, obtaining high values for the Jersey breed, however the data thrown for each parameter evaluated are within the viable seminal ranges that are cited by several authors.

The conclusions derived in the determination of differences between the values of the seminal quality by means of the conventional method and with the CASA system, there are differences in all the cases, in this effect it can be mentioned that the systems seminal analysis assisted by computer provide measurements more reliable, impartial and repeatable, compared to the conventional exam.

\section{REFERENCES}

[1] Agüero, G. (2012). Evaluación de las Características Seminales de Sementales Bovinos mediante el Analizador Seminal Computarizado (CASA) . UNIVERSIDAD CENTRAL DE VENEZUELA.

[2] Barth, A. (2001). Importancia de la calidad seminal y el uso de FIV para el estudio de efectos espermáticos. Memorias V Simposio Internacional de Reproducción Animal- INRA

[3] Bernardi, S., Allende, R., Mazzeo, R., Monti, J., \& Marini, P. (2011) Evaluación de los cambios ocasionados en espermatozoides bovinos por variaciones en el manejo de las dosis durante su manipulación en inseminación artificial. InVet vol.13 no. 2 .

[4] Boggio, J. (2007). Evaluación de la aptitud reproductiva potencial y funcional del toro. Valdivia: Universidad Austrial de Chile.

[5] Brito, L., Silva, A., Rodríguez, L., Vieira, F., Deragon, L., \& Kastelic, J. (2002). Effects of environmental factors, age and genotype on sperm production and semen quality in bos indicus and bos taurus ai bulls in brazil. Animal Reproduction Science, 71

[6] Buzón Cuevas, A. (2013, Septiembre ). Análisis cinético y morfométrico del espermatozoide del caballo empleando el sistema Sperm Class Analyzer. Universidad de Cordova, 173

[7] Cabrera, P., \& César, P. (2012). Viabilidad espermática e integridad del acrosoma en semen congelado de toros nacionales. Revista de Investigaciones Veterinarias del Perú.

[8] Catena, M., \& Cabodevila, J. (1999). Evaluación de semen bovino congelado. Sitio Argentino de Producción Animal, 9.

[9] Cuberlo, M., \& Rodríguez, Z. (2013). Revelantamiento de laboratorios de procesamiento de semen bovino en Uruguay. Universidad de la República

[10] Díaz, M., García, P., \& Rodríguez, M. (1989). Técnica de Inseminación Artificial en el Conejo. Ministerio de Agricultura Pesca y Alimentación, MADRID.

[11] Farrell, P., Presicce, G., Brockett, C., \& Foote, R. (1998). Quantification of bull sperm characteristics measured by computerassisted sperm analysis (CASA) and the relationship to fertility. Theriogenology, 871-879.

[12] Gadea, J. (1997). Predicción de la fertilidad "in vivo" de los eyaculados de verraco mediante parámetros rutinarios de contrastación seminal, pruebas bioquímicas y el test homólogo de penetración "in vitro". Universidad de Murcia , 116.
[13] Gadea, J. (2001). La evaluación de la capacidad fecundante de los espermatozoides porcinos mediante la fecundación in vitro. Universidad de Murcia.

[14] Gomez, V., \& Migliorisi, L. (2015). Protocolo para la evaluación de semen en rumiantes. Sitio Argentino de Producción Animal.

[15] González, J., Martínez, Y., \& Sánchez, D. (2013). Análisis seminal equino y bovino. Espermatozoides In Vitro, 5

[16] Guzmán, N. (2013). Evaluación seminal en toros por métodos manuales o computarizados. Universidad de la República.

[17] Hafez, E., \& Hafez, B. (2000). Reproducción e Inseminación Artificial en Animales. Kiawah Island, South Carolina USA: McGraw-Hill Interamericana.

[18] Hernandez, D., \& Carrillo-Gonzales, D. (2015). Aplicación del tes hipoosmotico (host) en la evaluacion de calidad seminal en ovinos criollos de pelo colombiano. Actas Iberoamericanas de Conservación Animal.

[19] Hidalgo, C., Tamargo, C., \& Diez, C. (2005). Análisis de semen bovino. Tecnología Agroalimentaria, 5.

[20] Hincapie, J. (2015). Evaluación de Semen bovino.

[21] Juarez, J. (2009, Septiembre). Efecto de la velocidad de enfriamiento en la congelabilidad de los espermatozoides de porcino. Master Interuniversitario en Mejora Genética animal y biotecnología de la Reproducción, 98.

[22] Kumar, U., Gawande, A., Sahatpure, S., Patil, M., K, L. C., Bonde, S W., . . Poharkar, A. a. (2015). Assessment of semen quality in pure and crossbred Jersey bulls. Veterinary World.

[23] Laboratorio de Estudios en Reproducción. (2016). Análisis de Semen Retrieved from http://www.lab-ler.com.ar/semen.php

[24] López, J., Urbano, A., \& Cárdenas, M. (2012). Manual de laboratorio para el analisis del semen.

[25] Lozano, H. (2009). Factores que afectan la calidad seminal en toros. Rev. Med. Vet. Zoot

[26] Madrid-Bury, N. (2005). ¿Es posible predecir la fertilidad en los toros? Manual de Ganadería Doble Proposito

[27] Medina, V., Sanchez, E., Velasco, Y., \& Cruz, P. (2007) Crioconservación de semen bovino usando un congelador programable (cl-8800) y determinacion de su calidad postdescongelacion por medio de un sistema de analisis espermatico asistido por computador (CASA). Universidad de Los Llanos.

[28] Mellisho, E. (2010). Evaluación seminal de calidad seminal. Manua de Laboratorio de Reproducción Animal, 7.

[29] Miró, M. (2015). Gestión de la reproducción en el macho.

[30] Moncayo, S. (2016, Enero). Evaluación de la calidad seminal de reproductores bovinos antes $\mathrm{y}$ despues del proceso de criopreservacion.

[31] Muiño Otero, R. (2008). EVALUACION DE LA MOTILIDAD Y VIABILIDAD DEL SEMEN BOVINO MEDIANTE EL USO DE SISTEMAS CASA Y CITOMETRIA DE FLUJO: IDENTIFICACION DE SUBPOBLACIONES ESPERMATICAS. Universidad de Santiago de Compostela.

[32] Muiño, R., Fernandez, M., Arean, H., Viana, J., Lopez, M., Fernandez, A., \& Peña, A. (2005). NUEVAS TECNOLOGIAS APLICADAS AL PROCESADO Y EVALUACION DEL SEMEN BOVINO EN CENTROS DE INSEMINACION ARTIFICIAL. 175 177.

[33] Padrón, R., Fernández, G., \& Gallardo, M. (1998). Interpretación del análisis seminal. Rev Cubana Endocrinol.

[34] Paez, E., \& Corredor, E. (2014). Evaluacion de la aptitud reproductiva del toro. Ciencia y agricultura, 11

[35] Palma, G. (2010). Determinación de la concentración de células espermáticas en el eyaculado. Biotecnologías de la reproducción.

[36] Perry, G., \& Patterson, D. (2017). Determinación de la fertilidad reproductiva de toros padres. Producción Animal.

[37] Quintero. (2003). Estudio sobre la dinámica de poblaciones espermáticas en semen de caballo, cerdo y conejo.

[38] Reproduccion Animal. (2014). Evaluacion del semen: Morfologia espermatica.

Tomadode://C:/Documents\%20and\%20Settings/SpermVision/My\% 20Documents/Downloads/1808544960.Laboratorio_8_Morfologia_ Espermatica_2011.pdf

[39] Restrepo, G. (2008). Biotecnologías reproductivas aplicables a la reproduccion bovina en Colombia. Medellin.

[40] Ribeiro, A., Munita, L., Yumi, M., Mello, M., \& Ferreira, F. (2014) Criopreservación de espermatozoides bovinos extraidos de la cola del 
epididimo utilizando los metodos convencional y automatizado. Universidad Austral de Chile.

[41] Rivera, M. (2013, 05 24). Manual de biotecnologia reproductivas en bovinos. Retrieved 08 28, 2016, from http://manualbiotecnologiareproductiva.blogspot.com/p/tecnicas-dereproduccon.html

[42] Rodríguez-Martínez. (2003). Laboratory semen assessment and prediction of fertility: still utopia? Reprod Domest Anim.

[43] Rouge, M. (2001). Counting Cells with a Hemacytometer. Colorado State University. Retrieved Junio 02, 2015, from http://arbl.cvmbs.colostate.edu/hbooks/pathphys/reprod/semeneval/h emacytometer.html

[44] Rubio, G., Gonzalez, D., Gonzalez, Y., Madrid Bury, N., \& Quintero Moreno, A. (2007). ¿Puede el ORT Complementar las Pruebas Clásicas de Valoración Seminal y Predecir.
[45] Rubio, J., \& Quintero, A. (2006). Uso de las pruebas de resistencia osmotica para valorar la funcionalidad espermatica en toros. ---: ---.

[46] Rutter, B., \& Russo, A. (2006). Bases para la evaluación de la aptitud reproductiva del toro. Buenos Aires.

[47] Sarabia, L. (2015). ESPERMIOGRAMA, Según los criterio de OMS 2012. $\quad$ Retrieved from https://es.scribd.com/doc/98228428/ESPERMIOGRAMA-Segunlos-criterios-de-la-OMS-5\%C2\%AA-Edicion.

[48] Serrano, A. (1993). Conceptos sobre la reproduccion en bovinos. 52.

[49] Urdaneta, R., \& Olivares, R. (1985). Colección, evaluación y procesamiento del semen de toros. FONAIAP.

[50] Vera Muñoz, O. (2008). Evaluación seminal comparativa pre y postcongelación en machos bovinos. Reproducción bovina.

[51] Vera Muñoz, O. (2008). Fisiología de los espermatozoides bovinos.

[52] Vera, C. A. (2011). Evaluación de la validéz de la cria y análisis de semen para predecir la fertilidad del toro. Universidad de Cuenca. 